\title{
Para além do verniz europeu: considerações sobre as gentes e cores na ocupação territorial do município de Cachoeira/RS
}

\section{Beyond the European varnish: considerations on people and colors in the territorial occupation of the municipality of Cachoeira/RS}

\author{
Aline Sônego* \\ https://orcid.org/0000-0003-1376-2154
}

\begin{abstract}
Resumo
O presente artigo tem como objetivo trazer algumas reflexões acerca da composição populacional do município de Cachoeira, localizado na região central do Rio Grande do Sul, tomando como ponto de partida a análise de materiais impressos como jornais e almanaques locais. Considerando que grande parte destes materiais tipográficos foram produzidos nas primeiras décadas do século XX, pretende-se compreender de que forma estes impressos contribuíram para construir percepções sobre as populações não brancas daquela região e a identificação de Cachoeira como um município de características populacionais e culturais europeias, uma vez que seu território também ter sido ocupado por imigrantes alemães e italianos. A partir da consulta aos relatórios e censos populacionais do século XIX, assim como, aos trabalhos historiográficos que pesquisaram sobre aquele espaço, percebe-se desde os primórdios uma importante presença numérica de não brancos. Neste sentido, confronta-se a invisibilidade expressa nos impressos analisados em relação às experiências sociais das populações negra e indígena como parte da tessitura social daquela região.

Palavras-chave: Impressos; invisibilidade; imigração europeia; negros e indígenas.
\end{abstract}

\begin{abstract}
The goal of this article is to reflect on the population composition of the municipality of Cachoeira, located in the central region of Rio Grande do Sul, taking as its bottom-line analysis of printed materials such as newspapers and local almanacs. Considering that a large part of these typographic materials was obtained in the first decades of the 20th century, it is intended
\end{abstract}

${ }^{*}$ Doutoranda em História pela Universidade Federal de Santa Maria (PPGH/UFSM). E-mail: aline_sonego788@hotmail.com 
to understand how these forms contributed to building perceptions about non-white populations in the region and the identification of Cachoeira as a municipality with a European population and cultural characteristics since its territory has also been occupied by German and Italian immigrants. From the consultation with population reports and censuses of the 19th century, as well as with the historiographical works that researched about that space, an important numerical presence of non-whites is perceived from the beginning. In this sense, the invisibility expressed in the analyzed forms is confronted in relation to the social experiences of the black and indigenous populations as part of the social fabric of that region.

Keywords: Printouts; invisibility; European immigration; black and indigenous people.

\section{Introdução}

A historiografia mais recente tem discutido e se contraposto a uma construção identitária que afirmava o Rio Grande do Sul como uma região de formação histórica e composição populacional essencialmente branca, cuja origem remonta a figura gaúcho, peão desarraigado, branco ou de miscigenação indígena longínqua, que a serviço de uma elite militar e proprietária portuguesa, permitiria a quase inexistência da escravidão na paisagem agrária sulina, interpretada como residual e benevolente. Com o passar dos anos, novos atores sociais foram incorporados e os imigrantes europeus, sobretudo alemães e italianos, passaram a ser somados nesta construção e vistos como agentes no progresso socioeconômico do estado meridional. As populações negra e indígena, por sua vez, foram invisibilizadas neste processo de construção identitária que recebeu aporte de escritores preocupados em descrever quem fazia parte da sociedade sulina, ${ }^{1}$ mas que também reverberou na forma como os diversos materiais impressos traziam e faziam circular esta percepção, contribuindo para consolidar esta visão entre os conterrâneos, assim como também para as demais regiões do país.

\footnotetext{
${ }^{1}$ Representantes desta historiografia rio-grandense, Alfredo Varella, Othelo Rosa, Aurélio Porto e Souza Docca concordam em seus escritos com predominância do tipo português na constituição do povo rio-grandense e, nas palavras de Othelo Rosa, "marcando decisivamente com suas peculiaridades raciais e psicológicas, o caráter do povo gaúcho, dando-lhe essa feição de um tipo branco de maior pureza" (Cf. GUTFREIND, Ieda. A Historiografia rio-grandense. $2^{\mathrm{a}}$ ed. Porto Alegre: Ed. Universidade/UFRGS, 1992, p. 94).
} 
Este artigo tem como objetivo compreender como essa construção se deu considerando um recorte regional, o município sul-rio-grandense de Cachoeira, analisando de que forma os impressos produzidos nas primeiras décadas do século XX contaram e representaram a história e a composição da sua população, estabelecendo critérios de representatividade que privilegiaram os brancos em relação aos não-brancos.

A abrangência territorial do município em questão passou por sucessivas modificações no decorrer dos séculos XIX e XX, como será discutido na segunda parte deste artigo. Dessa forma, optou-se pelo mapa que representa a localização de Cachoeira dentre os demais municípios do estado do Rio Grande do Sul em 1920, cuja extensão espacial corresponde mais especificamente ao contexto em que os materiais impressos pesquisados foram produzidos.

Mapa: Municípios do Rio Grande do Sul - 1920

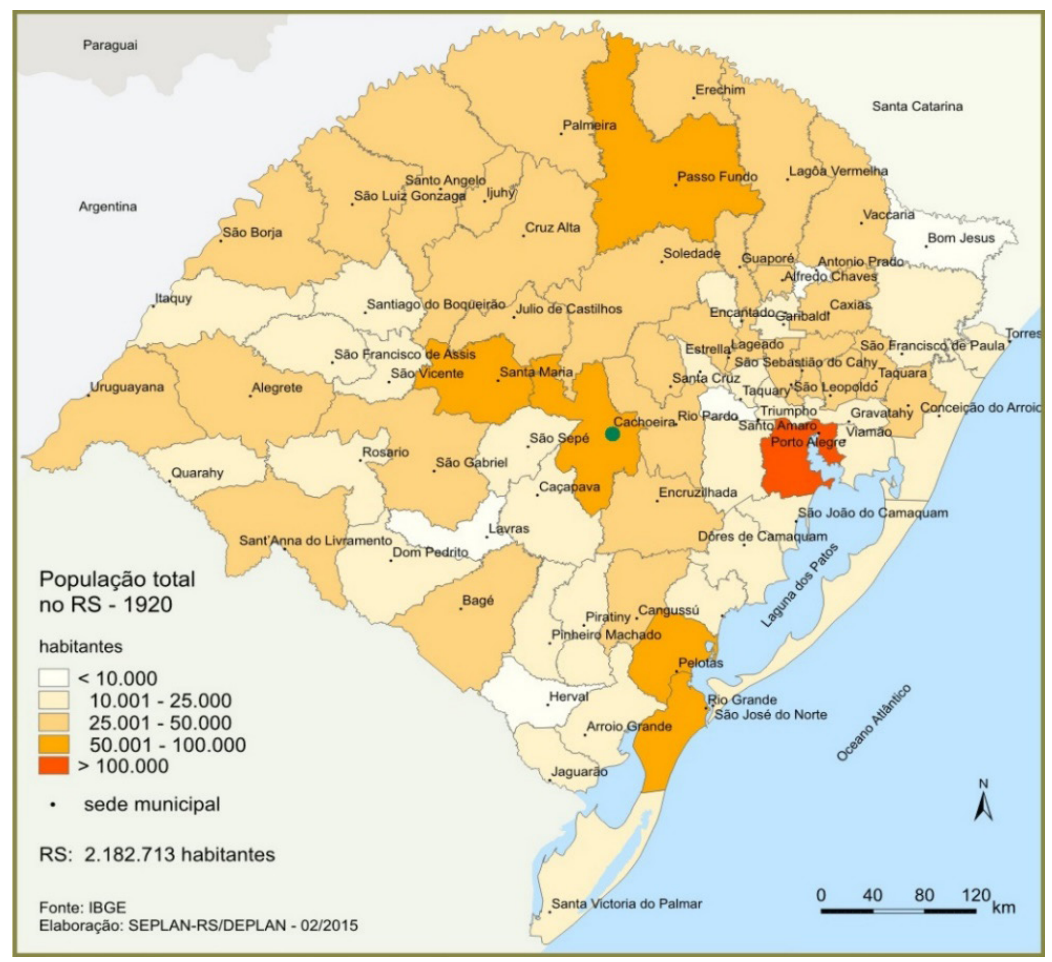

Fonte: Atlas Socioeconômico Rio Grande do Sul. Porto Alegre: Secretaria do Planejamento, Governo e Gestão, 4 ed. 2019. ${ }^{2}$

${ }^{2}$ A localização da sede do município representada pelo ponto em verde (grifo meu). Atlas disponível em: $<$ https://atlassocioeconomico.rs.gov.br/demografia-1872-a-1980>. Acesso em 07 jul. de 2021. 
Inicialmente, se analisará os diversos materiais tipográficos produzidos localmente, tais como jornais comerciais, almanaques comemorativos e textos produzidos pela historiografia no referido período e que também circulavam pelos periódicos locais. A partir dessas fontes, se discutirá sobre uma construção identitária que lia e refletia uma sociedade local como essencialmente descendente de europeus, uma vez que a existência de uma população não-branca no município foi apagada, ou em alguns momentos, mitificada naqueles impressos.

Após privilegiar uma análise que visa compreender como, em nível cultural, os materiais impressos contribuíram para a construção de um município essencialmente branco e de origem europeia, foi necessário buscar as fontes que trouxessem uma dimensão quantitativa da composição populacional. Neste sentido, a segunda parte deste artigo analisará os dados censitários desde o início do século XIX, assim como os estudos historiográficos realizados para a região e que trazem a dimensão da estrutura escravista no município e que utilizaram, especialmente, os inventários pos-mortem e as cartas de alforria. A consulta a essas fontes e estudos trouxe, por sua vez, uma contraposição à composição populacional preconizada ou defendida pelos materiais impressos consultados sobre Cachoeira, descontruindo historicamente a referida ausência de negros, pardos e indígenas na contribuição da formação da população da região.

\section{O mito e o escrito: representações sobre a população negra e indígena em Cachoeira}

As primeiras décadas do século XX são marcadas pelo surgimento e popularização de materiais tipográficos destinados a trazer dados históricos, geográficos e estatísticos das cidades e municípios. Presentes tanto nas capitais quanto nas cidades do interior do país, as publicações desse gênero foram profusas. Eram almanaques geralmente publicados em datas comemorativas, como aniversário da fundação do município e de alguma outra efeméride importante para aquela localidade e que contavam com ilustrações, fotografias e publicidade do comércio e das industriais locais. Para a historiadora Heloísa Cruz:

Os almanaques transformam-se em verdadeiros guias da cidade, incorporando de forma crescente informações sobre suas instituições, seus hábitos e espaços de cultura e entretenimento, recantos aprazíveis, estabelecimentos de ensino, associações 
recreativas, clubes de esportes, trazendo como novidade indicadores comerciais e de profissões. ${ }^{3}$

Cachoeira, um dos municípios do interior do Rio Grande do Sul, não ficou de fora dessa tendência tipográfica e foi contemplado com algumas publicações do estilo. A partir delas, é possível analisar como a sociedade se percebia, ou melhor, a forma como gostaria de ser retratada por seus contemporâneos e, quiçá, para a posterioridade, uma vez que os historiadores utilizam essa fonte para obter informações sobre variados aspectos da cultura urbana do período. ${ }^{4}$ Nas publicações consultadas, constata-se uma representação de uma Cachoeira pujante, que colhe os frutos do progresso promovido pela cultura do arroz, sendo os sobrenomes alemães e italianos os que mais estampam a publicidade do comércio e da indústria cachoeirense. A Cachoeira retratada nos almanaques parecia reforçar as palavras escritas por Aurélio Porto, em 1934, sobre o trabalho alemão no Rio Grande do Sul:

Construtores humildes da riqueza, espalharam-se pelos campos, pelas cidades, rompendo fronteiras das colônias e, onde surgiam, as indústrias prosperavam, um novo sôpro de vida intensificava a atividade multiplicadora de nossas possibilidades econômicas. ${ }^{5}$

O autor da passagem citada, o cachoeirense Aurélio Porto (1879-1945) desempenhou atividades de jornalista, professor, literato e historiador. É o primeiro autor que se dedicou à compilação dos registros históricos de Cachoeira do Sul, elaborando o texto Município de Cachoeira, história e estatística, de $1910 .^{6}$ Partes desta obra foram publicadas nos almanaques locais e os posteriores trabalhos historiográficos locais são reprodutores de suas pesquisas sobre a história do município. Filiado ao Partido Republicano Rio-Grandense, foi indicado para exercer a função de Intendente nos municípios de Garibaldi (1913-1917) e Montenegro (1923-1924), porém o maior destaque na atuação de Aurélio Porto foi enquanto funcionário público no Museu do Estado, com a cedência para pesquisas no Arquivo Nacional do Rio de Janeiro. ${ }^{7}$

\footnotetext{
${ }^{3}$ CRUZ, Heloísa de Faria. São Paulo em papel e tinta: periodismo e vida urbana (1890-1915). São Paulo: Arquivo Público do Estado de São Paulo, 2013, p. 58.

${ }^{4}$ Entre as publicações de Cachoeira destaca-se: PORTELA, Vitorino de C., PORTELA, Manoel de C. Cachoeira histórica e informativa. Cachoeira: Tipografia Portela, 1940; CAMOZATO, Benjamin C. (Org.) Grande álbum de Cachoeira no Centenário da Independência do Brasil. Cachoeira do Sul: Município de Cachoeira, 1922.

${ }^{5}$ PORTO, Aurélio. O trabalho alemão no Rio Grande do Sul. Porto Alegre: Martins Livreiro, 1996, p. 263.

${ }^{6}$ PORTO, Aurélio. Cachoeira. Resumo Histórico. In: CAMOZATO, Benjamin C. (Org.). op. cit, s.p.

${ }^{7}$ CAMPOS, Vanessa Gomes de (Org.). Guia arquivos pessoais e coleções IHGRGS. Porto Alegre: Instituto Histórico e Geográfico do Rio Grande do Sul, Secretaria de Estado da Cultura do Rio Grande do Sul, 2013, p. 19.
} 
Como membro-fundador do Instituto Histórico Geográfico do Rio Grande do Sul (IHGRS), a produção intelectual de Aurélio Porto encontrava-se enredada em uma teia de relacionamentos, onde suas posições intelectuais estavam condicionadas aos posicionamentos políticos dominantes, convergindo na construção de um discurso historiográfico compatível com a orientação política vigente, que, segundo Jefferson Martins Teles, também gerava limitações no campo intelectual e não imune de conflitos internos. ${ }^{8}$ Porém, para além das dissidências intelectuais internas, havia um ideário corrente estimulado pela vertente positivista adotada pelo grupo político dominante do estado em justificar e reforçar a ideia de uma marcha rumo ao progresso e desenvolvimento no Rio Grande do Sul, ancorado em construção historiográfica que enfatizava a presença de um povo diferenciado do restante do país, em que a raça branca era preponderante e foi reforçada pela atuação do "laborioso elemento europeu".

Marcus Vinicius de Freitas Rosa, no primeiro capítulo de sua obra, trata sobre como três bacharéis gaúchos dedicaram-se em seus escritos em construir a imagem do Rio Grande do Sul como uma província branca. Segundo o autor, essa imagem já não era novidade, mas foi reabilitada naquele contexto de crise monárquica e do escravismo. Como se observa, a imagem continuou sendo reforçada e justificada pela produção historiográfica, posteriormente elaborada especialmente pelo IHGRS. ${ }^{9}$

Os almanaques e alguns artigos publicados nos jornais cachoeirenses, refletem esse panorama ideológico e econômico transposto do nível estadual para o local. Jeferson Selbach, em sua tese de doutorado, argumentou que uma elite cachoeirense advinda dos núcleos coloniais de imigrantes bem-sucedidos agregou-se à elite de origem portuguesa, proprietária de grandes estâncias dedicadas à atividade pecuária no município e, conjuntamente, traçaram a sua participação unívoca na história do município. Embora de contextos distintos, essas elites "teriam em comum o fato de se diferenciarem dos demais habitantes, não só pelas riquezas adquiridas no período, mas por hábitos e costumes próprios, algo que os caracterizava como grupo distinto, construindo peculiar personalidade e identidade". ${ }^{10}$ Isto é, ambos se fortaleciam enquanto grupo

\footnotetext{
${ }^{8}$ TELES, Jefferson M. O Instituto Histórico e Geográfico do Rio Grande do Sul e o espaço social dos intelectuais: trajetória institucional e estudo das redes de solidariedade (e conflitos) entre intelectuais (1920-1956). Tese (Doutorado em História), Pontifícia Universidade Católica do Rio Grande do Sul, 2015, pp.154-155.

${ }^{9}$ ROSA, Marcus Vinicius de F. Além da invisibilidade: história social do racismo em Porto Alegre durante o pós-abolição. Porto Alegre: EST Edições, 2019.

${ }^{10}$ SELBACH, Jeferson F. Muito além da Praça José Bonifácio: as elites e os outsiders em Cachoeira do Sul pela voz do Jornal do Povo, 1930-1945. Tese (Doutorado em História), Programa de Pós-graduação em História, UNISINOS, 2007, p. 111.
} 
dominante e reforçavam a imagem de Cachoeira como um município predominantemente de origem europeia, seja ela lusitana ou alemã. A maioria dos trabalhos historiográficos sobre o município, em maior ou menor grau, acaba por reforçar essa posição, dando um protagonismo maior para as experiências sociais da colonização europeia no período.

A partir dessa perspectiva, identifica-se que nas publicações do início do século XX que retrataram o município de Cachoeira não houve espaço para descrever as contribuições de outras populações além daquelas de descendência europeia. Aliás, se outras populações que existiram por ali, especialmente a população negra, são retratadas como parte do passado, em um tempo longínquo o suficiente para transformar-se em uma lenda. É o que se pode perceber ao analisar a narrativa "Rita dos Cachos", presente na Cachoeira Histórica e Informativa, de Vitorino e Manoel de Carvalho Portela. ${ }^{11}$ Esta é a única menção a presença dos negros em Cachoeira na referida obra e está ligada ao sofrimento de um passado escravista. A narrativa apresenta uma mulher escravizada que perdeu a sanidade ao ter seu filho vendido a outro senhor. Ao final da narrativa, a conclusão:

(...) a história da Rita do Cachos é uma verdade genuína, pois, em Cachoeira existem ainda numerosas pessoas que conheceram e se condoeram das desditas de uma das tantas vítimas, como Rita, da escravidão, que a nobre Princeza Izabel, dando vazão aos seus sentimentos de formossisimo coração de "Mãi dos Brasileiros" fez extinguir para sempre, nesta abençoada terra de Santa Cruz, pela Lei áurea de $1888 .^{12}$

Para além do destaque dado ao papel libertador dado a Princesa Isabel, chama a atenção nessa narrativa o fato que o narrador explica que existiam ainda, naquela ocasião da publicação, ou seja, década de 1940, pessoas que conheceram e acompanharam a vigência da escravidão. Porém, o relato omite quaisquer informações sobre as vítimas do cativeiro após a Lei Áurea. Estas teriam "sumido do mapa" e da história de Cachoeira, assim que foi assinada a abolição, restando apenas os relatos de quem as conheceu?

\footnotetext{
${ }^{11}$ Os irmãos Vitorino e Manuel Portela eram jornalistas e naturais de Alegrete. Vitorino também era historiador e dirigia o semanário O Alegretense. Manuel faleceu em Cachoeira em 1951 e Vitorino em Porto Alegre em 1958 (RITZEL, Mirian Regina Machado. Dicionário Bibliográfico Cachoeirense: natos e adotivos. Porto Alegre: Martins Livreiro, 2006. pp.44-45).
}

${ }^{12}$ PORTELA, V. de C., PORTELA, M. op. cit., p.97. 
Outra publicação da imprensa cachoeirense do início do século XX, o jornal Rio Grande, narrou a devoção popular a Santa Josefa, ${ }^{13}$ escravizada que teria sido morta pelo seu senhor, apesar do seu comportamento dado como obediente e sensato. $O$ cronista identificou-se como João da Ega, pseudônimo utilizado por Aurélio Porto na imprensa. ${ }^{14} \mathrm{~A}$ história em torno da escrava Josefa simboliza a crueldade de uma instituição, que, aos olhos do narrador, em 1911, já foi a muito superada e ressignificada em forma de santificação:

O povo santificou-a. E ela vem até nós, há quase um século, trazida pela crença onisciente do povo, o seu santificador. As gerações têm passado sobre ela, respeitando-a e venerando-a. É para nós, que não temos a ventura de crer, uma tradição simbólica da terra. E amamo-la porque ela será, quando a cidade remodelada e modernizada arrasar os últimos vestígios do passado, o refúgio da tradição cachoeirense, a ara velha do templo em ruínas do passado em que iremos comungar com essa raça forte, afetiva e infeliz que terá naquele túmulo o pedestal de seu martírio. ${ }^{15}$

Ao santificar a escravizada Josefa, ocorre uma transmutação do seu considerado bom comportamento em uma característica divina, fora do padrão e, por isso, digna de aproximar-se dos ideais cristãos. Esse fato motivou uma campanha para mobilizar a comunidade de Cachoeira em torno da construção de uma capela em sua homenagem ${ }^{16}$, isto é, ao ser santificada, na religiosidade dominante no período, ela é cristianizada. Esse procedimento não era estranho no Rio Grande do Sul. Elomar Tambara ao analisar a lenda do Negrinho do Pastoreio afirma que, com o passar todo tempo, a lenda foi se adequando aos elementos do cristianismo, principalmente a partir da sua releitura expressa

\footnotetext{
${ }^{13}$ Dante Laytano cita a lenda de Santa Josefa como pertencente ao ciclo negro das lendas e folclores sul-riograndenses e a sua abundância de material folclórico devido à herança que as populações africanas herdaram de seus antepassados. LAYTANO, Dante. O negro no Rio Grande do Sul. Terceira parte- aspecto folclórico-ciclo das lendas no Rio Grande do Sul. Estudos Ibero-americanos, XXI (2), dezembro, 2005, pp.187201. Ainda que Laytano tenha uma abordagem pouco analítica e impregnada de sua visão de mundo enquanto intelectual branco, inspirado na leitura de Gilberto Freyre para a sociedade brasileira, foi o primeiro a colocar a população negra como integrante na formação do "povo gaúcho", de acordo com Maurício Lima. LIMA, Maurício L. Interfaces entre Gilberto Freyre e Dante Laytano: a "democracia gaúcha”. Semina, v. 12, nำ1, 2013.

${ }^{14}$ CAMPOS, Vanessa Gomes de (Org.). op. cit. p.19.

${ }^{15}$ EGA, João da. Jornal Rio Grande, 16 de novembro de 1911. Cachoeira, Rio Grande do Sul. Anno VII, n 80, p.1. Arquivo Histórico de Cachoeira do Sul.

${ }^{16}$ A Lei n. 58 de 19 de março de 1917 autorizou a doação de um terreno para edificar uma capela para Santa Josefa (MENSAGEM apresentada pelo Intendente Capitão Francisco Fontoura Nogueira da Gama ao Conselho Municipal em 20 de setembro de 1917, p. 33-34. Arquivo Histórico de Cachoeira do Sul).
} 
no conto de Simões Lopes Neto, que foi amplamente conhecido e divulgado nos ambientes escolares. ${ }^{17}$

Publicada no jornal 0 Commercio de 1918, outra crônica traz elementos interessantes para pensar as representações sobre a população não-branca e suas experiências sociais. A narrativa trata sobre a rivalidade pelo amor de um homem entre duas mulheres, preta Inês e a cabocla Micaela. A primeira, paupérrima, morreu de desgosto ao saber do envolvimento de seu amor com Micaela, dita como adepta de feitiços e bruxarias, que teriam causado a morte do amante. As duas sangas, onde, nas suas proximidades, residiam as referidas mulheres, foram posteriormente denominadas Sanga da Inês e Sanga da Micaela. A lenda urbana indica ainda que, quando essas sangas se encontrarem, motivadas pela rivalidade daquelas mulheres, abrir-se-á uma grande erosão no solo, de tal forma que a cidade de Cachoeira desaparecerá. ${ }^{18}$

Bastante conhecida na região, a referida história retrata as populações não-brancas de Cachoeira, construindo, no imaginário popular, identificações estereotipadas dessas mulheres como degradadas social e economicamente e como feiticeiras, cujos males que estão embrenhadas podem espalhar-se e prejudicar uma cidade inteira. Seriam as sangas uma analogia a um passado bárbaro, incivilizado e incontrolável que precisa ser contido para não ameaçar a cidade civilizada? Seria ao acaso a identificação com uma preta e uma cabocla como potenciais destruidoras da urbe?

Alguns anos antes, o jornal 0 Commercio também noticiava sobre o triste destino do preto Bonifácio. Na passagem, o fato de sua morte ao relento misturava-se com as narrativas populares e preconceituosas sobre sua vida, dando-lhe o status lendário na cidade:

"O BONIFACIO" Na noite de quinta para sexta-feira amanheceu morto, enregelado, debaixo de um galpão aberto, á rua Conde de Porto Alegre (caminho do Amorin) o preto Bonifácio, muito conhecido por toda a cidade. Meio disforme e accentuadamente cretino, o pobre homem vagava sempre pelas ruas, recorrendo á caridade. Pouco falava. Estendia a mão sorrindo e por isso ninguém se compadecia muito de sua sorte. Em torno de sua pobre individualidade fez-se uma lenda que muito o prejudicava. Dizia-se que era um hábil batedor de galinheiros, acto que

\footnotetext{
${ }^{17}$ TAMBARA, Elomar. A leitura escolar como construção ideológica: o caso na lenda do Negrinho do Pastoreio (1857-1906). Revista História da Educação, v. 9, ํ17, janeiro/junho, 2005, pp. 81-96.

${ }^{18}$ JORNAL O Commercio, 14 de agosto de 1918. Cachoeira, Rio Grande do Sul. Anno XIX, nº 976. Arquivo Histórico de Cachoeira do Sul.
} 
transmudava seus movimentos pesados e sonolentos em vertiginosas corridas, quando apercebido pelos donos dos galinheiros. Esta lenda injusta e mallevola lhe acarretava grande abstenção nas esmolas e faziam-n'o quase um réprobo, a quem negavam geralmente não só alimentos, como agasalho. Não tinha o menor abrigo. Dormia normalmente na rua. O seu destino era, portanto, o que teve: morrer de frio, visto que a nossa assistencia publica a esses miseráveis ainda não está organizada. ${ }^{19}$

Digno de pena, a miserabilidade de Bonifácio era percebida por todos na cidade, mas sua má fama de larápio de galinhas justificou aos olhos do noticiador a sua situação social e, inclusive, a sua triste sina de morrer de frio. Sidney Chalhoub indica que a suspeição sobre os mais pobres, principalmente as pessoas de cor, foi uma construção social sedimentada por toda uma legislação que visava controlar e coibir aqueles que alcançaram a liberdade no 13 de maio. O autor traz que as expressões "classes pobres" e "classes perigosas" passaram a denotar quase que a mesma "realidade" no final do século XIX. $^{20}$ Esse raciocínio estava implícito na preocupação dos parlamentares brasileiros em legislar, naqueles meses derradeiros a abolição da escravidão, sobre o destino dos libertos e ausência do trabalho compulsório. O trabalho era considerado uma virtude não inata aos ex-escravizados e na ausência da obrigação eles se entregariam à ociosidade. Concluía-se, assim, que o pobre que não conseguia acumular recursos, não era um bom trabalhador. O vício da ociosidade o levaria à propensão de cometer delitos, tornando-se perigoso e passível de suspeição pelos seus atos. ${ }^{21}$

Na mesma passagem da notícia da morte de Bonifácio, a frase final também merece destaque: "nossa assistência pública a esses miseráveis não está organizada”. Nas décadas iniciais do século XX, o discurso higienista e

\footnotetext{
${ }^{19}$ JORNAL O Commercio, 16 de agosto 1916. Cachoeira, Rio Grande do Sul. Anno XVII, nº 872, p. 2. Arquivo Histórico de Cachoeira do Sul. Grifo meu.

${ }^{20}$ CHALHOUB, Sidney. Cidade Febril. Cortiços e epidemias na Corte Imperial. São Paulo: Companhia das Letras, 1996, p. 19.

${ }^{21}$ No livro de registros da Delegacia de Polícia de Cachoeira, de 1887, são frequentes os relatos da polícia particular informando sobre as rondas noturnas e a coibição feita aos negros e negras que estivessem nas vias públicas em atitudes sob suspeição. É o caso relatado pelo sargento da polícia particular, Antero Marcelino da Silva, dirigida ao Delegado de Polícia, Hilário José de Barcellos, em 20 de novembro de 1887, que não houve novidades na ronda, exceto a patrulha de Muniz e Galdino que "apitando socorro, acendi logo donde partia o apito rua General Portinho e ahi efectuaram-se a prisão de Maria, escrava de Barão de Von Kaldhen e de Marcellino de tal por ofensas a moral e fiz ambos recolher a cadeia (...) As $81 \frac{1}{2}$ horas da noite mais ou menos foram por mim presas a preta Jacintha, escrava de D. Ana Pereira, e a parda Joaquina, em fragrante, por crime de furto de farinha na padaria do sr. Antonio Domingos, e imediatamente fiz ambas recolher a cadeia". Delegacia de Polícia. Cachoeira. 1887. Arquivo Histórico de Cachoeira do Sul.
} 
eugênico misturou-se à periculosidade das classes populares. Este era o momento em que a administração da cidade devia preocupar-se com os mendigos e todos os transtornos que trazem a urbe civilizada. A notícia, mais que informar a morte do pobre mendigo, estava corroborando para uma construção da memória coletiva na cidade que não dizia respeito somente a Bonifácio, mas àqueles que se encontravam em situação semelhante.

Paulina Alberto tem se dedicado a investigar a trajetória de Raúl Grigera, artista negro portenho que fez sucesso na Argentina nas primeiras décadas do século XX..$^{22} \mathrm{O}$ principal interesse da historiadora reside em perceber a forma como a memória coletiva sobre a vida de Raúl constitui um exemplo de ocultamento das populações negras naquele país. Pensadores e políticos argentinos dedicaram-se a incentivar a imigração e a promover àquela nação o status de exceção europeia branca, em meio a um continente marcado pela grande presença da população indígena, africana e de descendentes da miscigenação racial. Para a historiadora, a branquitude também prevaleceu na Argentina através da narrativa: nos censos populacionais, na literatura, na história, nas estátuas, nas artes, nas genealogias, entre outros, buscava-se enfatizar uma moderna e europeia Argentina, relegando a população negra a ideia de que fez parte apenas de um passado distante daquela nação. A história de vida del negro Raúl recebeu muitas versões no decorrer das décadas do século XX e, na maioria delas, trazem-no enquanto uma figura lendária e carregada de estereótipos, constituindo-se o que Paulina Alberto denomina de histórias raciais: contos persuasivos, que, com o poder empático da narrativa, dão vida às ideologias raciais e auxiliam na sua difusão, naturalização e reforço através do discurso popular.

As fontes que a historiadora utilizou foram, na maioria, ensaios ou histórias em revistas literárias e culturais, artigos de revistas e jornais sobre a história das cidades ou bairros. Lendas, crendices e histórias cuja oralidade popular permitiu o surgimento de muitas versões que são apropriadas pelo discurso escrito narrativo e reelaboradas no contexto em que são contadas, carregadas de sentidos e intencionalidades. Isso reforça, como no exemplo das publicações de Cachoeira expostas anteriormente, sobre como a utilização dos impressos são importantes na construção das identidades sociais e na historicidade de uma cidade, de um estado ou de um país. As histórias populares descritas possuem um núcleo narrativo comum: a ideia de um passado negro, escravista, que foi reelaborado e superado. Novos ares circulam por

${ }^{22}$ ALBERTO, Paulina L. El Negro Raúl: Lives and Afterlives of an Afro-Argentine Celebrity, 1886 to the Present. Hispanic American Historical Review, v. 96, n. 4, 2016, pp.669-710. 
Cachoeira e o seu passado sobre as vivências das populações negras é remoto e lendário, no limite do inverossímil.

Nesse sentido, se faz necessária uma breve contextualização da ocupação territorial de Cachoeira, buscando identificar sua composição étnica, verificando se o vácuo da representação da população negra na região justifica-se pela baixa presença demográfica em relação aos descendentes de imigrantes europeus ou se seria parte de um projeto regional de construção da invisibilidade das populações negras e indígenas. ${ }^{23}$

\section{"Nem raro, nem claro": ${ }^{24}$ a desconstrução histórica de uma Cachoeira branca}

A história da população negra em Cachoeira iniciou-se juntamente ao contexto de ocupação daquele território pelos portugueses, após as sucessivas disputas territoriais com os espanhóis no século XVII. ${ }^{25}$ Através da distribuição aos militares de grandes lotes de terras - as sesmarias -, iniciou-se a ocupação daquela região com a atividade agropastoril, em que a mão de obra escravizada se fez presente desde o início. ${ }^{26}$ Escravizados como Tereza, Benguela, de 20 anos; da pequena Eva, mulata, de aproximadamente um ano; de Joaquim, de 30 anos; Benguela, de Domingos, Monjolo, de 25 anos e do menino Francisco de 12 anos, Benguela, estavam entre os primeiros habitantes negros da região. ${ }^{27}$ Como eles, tantos outros escravizados ali habitavam e realizavam todo tipo de serviço naquelas primeiras estâncias agropastoris. Alguns deles, como a parda Maria, conquistaram a alforria do seu senhor Manoel Carvalho da

\footnotetext{
${ }^{23} \mathrm{O}$ uso desse termo está relacionado à análise de Marcus Vinicius de Freitas Rosa com a qual se dialogou intensamente para a concepção deste artigo (ROSA, op. cit.).

${ }^{24}$ Expressão utilizada no título do livro de poesias do poeta e filósofo negro Ronald Augusto. AUGUSTO, Ronald. Nem raro, nem claro. Porto Alegre: Butecanis Editora Cabocla, 2015.

${ }^{25}$ OSÓRIO' Helen. Apropriação de terra no Rio Grande de São Pedro e a formação do espaço platino. Dissertação (Mestrado em História). Programa de Pós-graduação em História, UFRGS, 1990.

${ }^{26}$ Paulo Roberto S. Moreira e Marcelo Santos Matheus analisaram as Relações de Matrículas de Escravos, dos anos de 1787 e 1788, depositadas no Arquivo Nacional e correspondentes às freguesias de São Luís de Mostardas, São Nicolau da Cachoeira e Senhor Bom Jesus do Triunfo. De acordo com os historiadores, juntas, as três freguesias informavam a matrícula de mais de mil cativos nas referidas freguesias. MOREIRA. Paulo R. S; MATHEUS, Marcelo. As matrículas de escravos da capitania de São Pedro do Rio Grande: análise dos plantéis de cativos das freguesias de Mostardas, Cachoeira e Triunfo - década de 1780. Anais do $6^{\circ}$ Encontro Escravidão e Liberdade no Brasil Meridional. UFSC, 2013.

${ }^{27}$ Inventário de Domingos Martins de 1777 (RIO GRANDE DO SUL. Secretaria da Administração e dos Recursos Humanos. Departamento de Arquivo Público. PESSI, Bruno Stelmach (Coord.). Documentos da escravidão: inventários, o escravo deixado como herança. Porto Alegre: CORAG, 2010, p. 22). Domingos Martins e Manoel Carvalho da Silva são, entre outros, alguns dos nomes citados por Aurélio Porto como os primeiros povoadores do território que constituiu o município de Cachoeira (PORTO, Cachoeira. Resumo histórico, op. cit.)
} 
Silva, constituindo também parte desse povoamento inicial de Cachoeira, um número crescente de libertos e seus descendentes. ${ }^{28}$

As grandes extensões territoriais também contavam com a ocupação por pequenos lavradores brancos, pardos e indígenas que se apossavam das terras pelo seu uso ou mesmo recorriam às autoridades solicitando a posse de porções de terras, o que propiciou, ao lado das grandes apropriações territoriais, a existência de pequenas propriedades na composição fundiária da região. ${ }^{29}$ Portanto, um grupo social bem mais heterogêneo participou deste processo de apropriação territorial, o que se pode inferir que desde o início a população de Cachoeira tinha uma composição étnica diversa.

Projetando também o entendimento da ocupação territorial de Cachoeira como um espaço em disputa pelas Coroas Ibéricas e, portanto, de caráter fronteiriço, evidencia-se a região como um lugar de circulação de pessoas de diferentes extratos sociais que se movimentaram pelo território em busca de oportunidades de vivência e sobrevivência.

Neste sentido, pensar os espaços territoriais ocupados por grupos sociais heterogêneos em busca de melhores condições também faz pensar sobre a mobilidade de indivíduos negros que, escravizados, fugiam. ${ }^{30}$ Por sua vez, como libertos e livres buscavam ampliar suas possibilidades a partir da

\footnotetext{
${ }^{28}$ Maria; Escolástica (sua mãe, Crioula, escrava do mesmo senhor); parda; Sr. Manoel Carvalho da Silva; dt. conc. 02-03-22; dt. reg. 02-03-22 (Livro 1, p. 96v). Desc.: A carta foi concedida "sem que ela seja obrigada a algum ônus ou compensação alguma, pelo beneficio que lhe faço". O senhor recebeu a escrava por herança de seus pais, o Tenente José Carvalho da Silva e Anacleta Faustina de Santana. O senhor pediu a Manoel Alves Ferras que a fizesse (RIO GRANDE DO SUL. Secretaria da Administração e dos Recursos Humanos. Departamento de Arquivo Público. Documentos da escravidão: catálogo seletivo de cartas de liberdade acervo dos tabelionatos do interior do Rio Grande do Sul. Porto Alegre: CORAG, 2006, p. 183).

${ }^{29}$ Luís Augusto E. Farinatti buscou compreender o processo de diversificação da estrutura produtiva no município de Santa Maria, no período de 1845-1880, no qual, a partir dos registros paroquiais de terra, percebeu o número significativo de lavradores nacionais, dedicados à produção de alimentos. Ocupando as áreas florestais, esses lavradores já faziam a contraposição ao que a historiografia rio-grandense tratou de discursar sobre a existência soberana das grandes estâncias de criação de gado. Para o autor, as áreas florestais das encostas da Serra não estavam "ociosas no aguardo de uma eventual colônia imigrante, estavam, sim, ocupadas por lavradores nacionais que sobreviviam da cultura de alimentos" (FARINATTI, Luís Augusto E. Sobre as Cinzas da Mata Virgem: Lavradores Nacionais na Província do Rio Grande do Rio Grande do Sul (Santa Maria, 1845-1880). Dissertação (Mestrado em História). Programa de Pós-graduação em História. Pontifícia Universidade Católica do Rio Grande do Sul, 1999, p. 40).

${ }^{30}$ Sobre a relação fronteira e a busca pela liberdade dos escravizados destacam-se as pesquisas: ARAÚJO, Thiago Leitão. Escravidão, fronteira e liberdade: políticas de domínio, trabalho e luta em um contexto produtivo agropecuário (vila de Cruz Alta, província do Rio Grande do Sul, 1834-1884). Dissertação (Mestrado em História). Programa de Pós-graduação em História, UFRGS, 2008; MATHEUS, Marcelo Santos. Fronteiras de liberdade: escravidão, hierarquia social e alforria no extremo sul do Império do Brasil (província do Rio Grande de São Pedro, Alegrete, 1829-1888). Dissertação (Mestrado em História). Programa de Pós-graduação em História. UNISINOS, 2012.
} 
migração. $\mathrm{O}$ viés de análise predominante na historiografia, questionado por Eduardo Neumann, coloca, na maioria das vezes, a questão de fronteira apenas em uma perspectiva dual, enfatizando as disputas entre lusos e hispânicos e esquecendo a existência de uma fronteira indígena que também lutava pela primazia daqueles territórios e tensionava as lutas fronteiriças. ${ }^{31} \mathrm{O}$ diálogo com uma historiografia que propiciou a ampliação do conceito de fronteira para além da perspectiva territorial limítrofe e demarcada de maneira fixa instigou a reflexão sobre contextos fronteiriços de forma mais abrangente, considerando que as trocas econômicas, políticas e culturais não se estacavam em espaços espacialmente delimitados, mas que se movimentavam e eram constituídos historicamente pelos sujeitos sociais envolvidos. ${ }^{32}$

Neste aspecto, as pesquisas de Rosicler Fagundes e Renata Oliveira ressaltaram Cachoeira também como parte desse processo de integração territorial fronteiriça. ${ }^{33} \mathrm{Em}$ 1819, Cachoeira foi o quinto município da Província de Rio Grande de São Pedro a ser criado, cujo território correspondia a uma grande parte do que mais tarde definiu-se como limites da atual unidade federativa. No decorrer do século XIX, outros núcleos populacionais que estavam administrativamente submetidos a Cachoeira cresciam em importância e passaram a ser emancipados..$^{34} \mathrm{O}$ processo de criação de novas vilas atendia simultaneamente aos objetivos locais e do poder central, visto que proporcionava a sua ingerência através da ampliação de agentes administrativos locais, propiciando uma maior centralização político-administrativa imperial, ao

\footnotetext{
${ }^{31}$ NEUMANN, Eduardo Santos. Uma fronteira tripartida: a formação do continente do Rio Grande - século XVIII. In: GRIJó, Luiz Alberto, et.al. Capítulos de história do Rio Grande do Sul. Porto Alegre: ed. UFRGS, 2005, pp.25-46.

${ }^{32}$ FARINATTI, Luís Augusto E. Confins Meridionais. Famílias de elite e sociedade agrária na fronteira sul do Brasil (1825-1865). Santa Maria: Ed. UFSM, 2010, pp. 86-88; THOMPSON FLORES, Mariana Flores da Cunha. Crimes de Fronteira: a criminalidade na fronteira meridional do Brasil (1845-1889). Tese (Doutorado em História). Programa de Pós-Graduação em História Pontifícia Universidade Católica do Rio Grande do Sul, 2012, p. 64.

${ }^{33}$ FAGUNDES, Rosicler Maria R. Esfaqueamento no Púlpito: o comércio e suas elites em Cachoeira do Sul na segunda metade do século XIX (1845-1865). Dissertação (Mestrado em História). Programa de Pós-graduação em História, UNISINOS, 2009; OLIVEIRA, Renata Saldanha. Cativosjulgados: experiencias sociais escravas de autonomia, sobrevivência e liberdade em Cachoeira do Sul na segunda metade do século XIX. Dissertação (Mestrado em História). Programa de Pós-graduação em História, UFSM, 2013.

${ }^{34}$ Alegrete e Caçapava elevaram-se a condição de Vilas em 1832, Santa Maria da Boca do Monte, em 1857 e, posteriormente, São Sepé, em 1876 (GIMENO, Alejandro J. F. Apropriações e comércio de terras na cidade de Cachoeira no contexto da imigração europeia (1850-1889). Dissertação (Mestrado em História). Programa de Pós-graduação em História. UFSM, 2014, p.28; SCHUH, Angela S.; CARLOS, Ione M. S. Cachoeira do Sul. Em busca de sua história; Porto Alegre: Martins Livreiro, 1991, p. 23).
} 
mesmo tempo em que aumentava o espaço de expressão política das pessoas de maior riqueza e prestígio especialmente através das Câmaras municipais. ${ }^{35}$

Apesar de dar conta de um território bastante vasto, o mapa da população de 1780 demostrou um pequeno contingente populacional no município de Cachoeira em relação às demais freguesias, composto por 6,3\% de brancos, $57,9 \%$ de indígenas e $35,8 \%$ de pretos. A disparidade também se apresenta em relação à composição etnorracial em no que se refere à totalidade de habitantes da província que apresentava um percentual de 52,36\% para brancos, $18,9 \%$ para indígenas e $28,47 \%$ para pretos. No censo de 1814 , o aumento populacional do município evidenciou-se trazendo dados indicativos também sobre a condição jurídica dos habitantes, sendo 4.576 indivíduos brancos, 425 indígenas, 398 livres e 2.622 escravizados. Comparado aos demais municípios, Cachoeira continha, no período, o maior percentual de escravizados, ${ }^{36}$ mas, em comparação ao percentual de brancos, a disparidade em termos da composição étnica populacional diminuiu em relação ao mapa populacional anterior, pois aproximadamente $55 \%$ dos habitantes de Cachoeira eram brancos e $31 \%$ eram escravizados. Os totais da província apresentavam um contingente de aproximadamente $47 \%$ de brancos e $28 \%$ de escravizados, ${ }^{37}$ revelando, portanto, pequena prevalência da população escravizada de Cachoeira em relação aos totais da província sulina.

Sobre a população indígena, ocorreu uma grande mudança no percentual de Cachoeira, sendo que antes se apresentava como majoritária e, no censo de 1814, caiu para 5\% dos habitantes. Provavelmente esses dados estão atrelados à especificação da região denominada Missões, onde havia o percentual composto de aproximadamente $80 \%$ de indígenas em comparação à população total daquela localidade e que, no censo de 1780, provavelmente, foi contabilizado como parte pertencente a Cachoeira. Deve-se atentar que esses dados censitários constituem parâmetros que devem ser relativizados em termos absolutos, pois compõem métricas cuja metodologia se desconhece. De qualquer forma, a participação da população indígena no povoamento de Cachoeira foi descrita com uma pequena passagem por Aurélio Porto no seu Resumo Histórico:

\footnotetext{
${ }^{35}$ COMISSOLI, Adriano. Povoamento e governança pública: elites locais e Câmaras municipais no sul da América portuguesa (1693-1810). In: REMEDI, José Martinho R. (Org). Na Fronteira do Império: política e sociedade na Rio Pardo oitocentista. Santa Cruz do Sul: EDUNISC, 2018, p.53.

${ }^{36}$ FAGUNDES, op. cit., pp. 44-46.

${ }^{37}$ Dados obtidos a partir da tabela população do Rio Grande do Sul por zonas e condição jurídica em 1814 cf. Ibidem, p. 46.
} 
(...) traz Gomes Freire grande numero de índios, já civilizados, das Missões, que faz arranchar nas proximidades do Butucarahy, de que lhes vem o nome butucarahys, individamente como pretendem alguns historiadores, dando como mandados a aldear por José Marcellino de Figueiredo, em 1779, na antiga aldea Passo do Fandango. ${ }^{38}$

Na segunda década do século XIX, em passagem pela província rio-grandense, os viajantes europeus Nicolau Dreys e August Saint-Hilaire já haviam destacado a presença indígena na formação do primeiro núcleo populacional de Cachoeira. Dreys relatou uma "Freguesia de Nossa Senhora da Conceição de Cachoeira, ainda pouco importante, posto se lhe haja reunido uma aldeia de índios que se vê perto daí, a população levanta-se, como as precedentes, na margem do Jacuí". ${ }^{39}$ Saint-Hilaire, por sua vez, descreveu Cachoeira:

Esta vila recém-criada, é ainda pequena; a praça pública está indicada por algumas casas esparsas. Entre a vila e o rio, sobre declive da colina, as miseráveis palhoças separadas umas das outras, cuja reunião toma o nome de Aldeia. Estas choupanas são habitadas por índios, que vieram da Aldeia de São Nicolau, vizinha a Rio Pardo, para lançar fundações desta vila e que aqui permaneceram após concluída sua empreitada. ${ }^{40}$

A passagem anterior diz respeito à prática colonial de incluir os indígenas aldeados na fundação dos primeiros núcleos populacionais da província como a aldeia de São Nicolau de Rio Pardo. A historiadora Karina M. R. da Silva Melo analisa a forma como os indígenas aldeados e cristianizados serviram à lógica inicial de fundação e ocupação territorial portuguesa, com concessões àqueles em detrimentos dos indígenas não-aledados, sendo estes perseguidos e assassinados. Porém, destaca que os indígenas aldeados também se entenderam dentro dessa lógica e buscaram garantir a continuidade de seu acesso à terra através dos mecanismos administrativos disponíveis. ${ }^{41}$ Isso foi especialmente necessário quando, garantido o domínio português, o território

\footnotetext{
${ }^{38}$ PORTO, Cachoeira. Resumo histórico, op. cit., s.p.

${ }^{39}$ DREYS, Nicolau. Notícias descritivas da província do Rio Grande de São Pedro do Sul. 4ed. Porto Alegre: Nova Dimensão, EDIPUCRS, 1990, pp. 88-89.

${ }^{40}$ SAINT-HILAIRE, Auguste de. Viagem ao Rio grande do Sul, 1820-1821. Belo Horizonte: Itatiaia; 1974, p. 338.

${ }^{41}$ A historiadora Karina Moreira Ribeiro da Silva Melo narra o episódio em que o índio Miguel Guaraci encaminhou à presidência da Província documento no qual pediu que fosse respeitada a concessão do privilégio de extração e preparo da erva-mate em Rio Pardo. MELO, Karina M. R. da Silva e. A aldeia de São Nicolau do Rio Pardo: identidades indígenas em construção. In: REMEDI, José Martinho R. (Org). op. cit., p. 13.
} 
passou a ser usurpado desses indígenas aldeados e loteado para colonos estrangeiros e nacionais. Expulsos ou empurrados, os indígenas migraram para formar novos núcleos populacionais. ${ }^{42}$

Em Cachoeira, esse processo de expulsão indígena após a consolidação do núcleo populacional pareceu bastante similar, conforme Aurélio Porto deixa escapar na sua narrativa: "A povoação já apresentava aspecto diverso. Casas de regular construção substituíam os ranchos da Aldea, já em declínio". ${ }^{43}$ Mas esse processo de "substituição" não foi tão rápido e nem imune a tensões, como se percebeu na documentação do início do século XX. Os relatórios da Intendência Municipal informavam sobre a necessidade de "resolver" a questão fundiária da localidade denominada Aldeia:

Situados em um recanto afastado da parte comercial da cidade, têm eles sido ocupados por gente pobre, na maior parte, porém preguiçosos, que ali se foram arranchando nos logares abandonados pelos indios e seus descendentes. (...) Estavam como já disse assim a ocupação de gente pobre, com preferencia ao aforamento delles quando o requeriam. Mas, salvo poucas excepções, esses ocupantes deixam de cultivar os terrenos gratuitamente occupados por tantos anos que seu exellente solo oferece. Além de algumas bananeiras e laranjeiras, alias velhas e péssimas, quase nada tem sido cultivado naqueles férteis terrenos, em geral cobertos de densa capoeira. É ingratidão que se revela, retribuindo o benefício da municipalidade e a generosidade daquele solo. Desse geito, enquanto todos terrenos da cidade e no município inteiro subiram, nos últimos annos, vertiginosamente de valor, os da Aldeia permaneceram, por assim dizer, sem valor algum. ${ }^{44}$

As palavras furtivas de Aurélio Porto para descrever a presença indígena na constituição do primeiro núcleo populacional de Cachoeira foram

\footnotetext{
${ }^{42}$ Marcelo Moura Mello ao pesquisar sobre a comunidade rural negra de Cambará, localizada próxima aos atuais limites entre os municípios de Cachoeira do Sul e Rio Pardo, percebeu as relações próximas entre africanos, afrodescendentes e indígenas partícipes da formação territorial da localidade, sendo que estes últimos, muitas vezes, eram registrados pelos párocos nos assentos batismais como pardos. MELLO, Marcelo Moura. Caminhos criativos da história: territórios da memória em uma comunidade rural negra. Dissertação (Mestrado em Antropologia Social). Programa de pós-graduação em Antropologia Social. UNICAMP, 2008, pp. 5-6.

${ }^{43}$ PORTO, Cachoeira. Resumo histórico, op. cit., s.p.

${ }^{44}$ RELATÓRIO de Estatística apresentado ao Sr. Capitão Francisco Fontoura Nogueira Gama- Vice-intendente em exercício pelo secretário do município Hermilio Pohlmann, 15 de setembro de 1915, p. 35-36. Arquivo Histórico de Cachoeira do Sul. Grifo meu.
} 
ainda mais escassas ao apresentar a presença negra no município. Em seu Cachoeira, Resumo histórico, constante no álbum comemorativo que celebrava o centenário da Independência do Brasil, a mão de obra escravizada aparece apenas quando o autor menciona a campanha abolicionista:

O Abolicionismo congregava clubs, procurava de todo modo facilitar a libertação dos escravos, a qual era feita sempre espontaneamente. Em 1 Junho de 1884 existiam no município 1305 escravos, dos quaes, por influxo da campanha abolicionista, foram libertados de 1 de Junho a 31 de Outubro deste anno 441, e de 1 de Novembro a 15 de Março de 1885, 178, ficando nesse decurso de tempo, livres 619. Como se vê eram bem aproveitados os trabalhos abolicionistas que encontravam em Cachoeira fervorosos e enthusiasticos adeptos. ${ }^{45}$

São muitos os aspectos implícitos nesta passagem. O primeiro deles seria destacar a existência de uma escravidão imediatamente atrelada a um eficiente movimento abolicionista. Portanto, Aurélio Porto não nega o inegável, a existência da escravidão no município, mas ao trazer os números de libertos, mostra-a como residual, quase inexistente. Dados bem menos otimistas ao que o historiador cachoeirense apresentou revelam que, em 1884, 93,24\% das alforrias concedidas aos escravizados em Cachoeira eram condicionais à prestação de serviço por um tempo determinado (variável de um a sete anos) ou pagamento de valor ao qual a prestação de serviço foi avaliada. ${ }^{46}$

A insistência em destacar o texto de Aurélio Porto justifica-se pela importância que a sua narrativa da história cachoeirense está vinculada a uma construção histórica que se coaduna com uma construção da história do Rio Grande do Sul que marcou profundamente a concepção de uma história da escravidão na província que há muito já foi refutada e desconstruída pela historiografia. Porém, a dimensão que esse tipo de construção histórica propagou na formação de uma memória nacional e regional tem efeitos a longo prazo nos quais as pesquisas acadêmicas que trazem as refutações nem sempre são absorvidas tão facilmente. ${ }^{47}$ Assim como em todo Rio Grande do

\footnotetext{
${ }^{45}$ PORTO, Cachoeira. Resumo histórico, op. cit., s.p.

${ }^{46}$ SÔNEGO, Aline. Sob a condição que continue em nossa companhia: As décadas finais da escravidão e a transição para o trabalho livre em um município rio-grandense. Dissertação (Mestrado em História). Programa de Pós-graduação em História, Universidade de Passo Fundo, 2011, p. 87. Em Rio Pardo, na última década de vigência da escravidão, 78,4\% das alforrias eram condicionais, cf. PERUSSATTO, Melina K. "A todo preto questionava se era livre ou escravo": considerações sobre a Rio Pardo escravista e desigual (1860-1888). In: REMEDI, José Martinho R. (Org). op. cit., p. 235.

${ }^{47}$ As obras de Aurélio Porto podem ser consideradas dentro do espectro de análise do que recentemente
} 
Sul, diversas pesquisas mais do que denunciaram o mito de uma escravidão branda ou residual na província. Neste sentido, a presente análise não está centrada em trazer argumentos inéditos sobre esse ponto já considerado pacífico da historiografia recente sobre a escravidão sulina, porém refletir sobre como a construção identitária que se fez sobre colocar determinadas etnias sobre outras.

O censo de 1859 é certamente o documento que traz informações sobre a composição populacional de Cachoeira que mais representa a dimensão territorial assumida pelo município no decorrer do século XIX, visto que os maiores desmembramentos territoriais já haviam sido realizados. Nessa composição populacional, Rosicler Fagundes observou que, de acordo com aquele censo, a população escravizada de Cachoeira era de 31\%, enquanto a população escravizada da província era de aproximadamente $25 \%{ }^{48}$ A população liberta de Cachoeira era incipiente, com aproximadamente $2 \%$. No entanto, cabe destacar que o censo relatava a condição jurídica e não a cor, portanto, entre os livres muitos poderiam ser indígenas, pardos e negros livres, não se configurando, portanto, um censo adequado para verificar a composição étnica de Cachoeira. Porém, somados os percentuais entre escravizados e libertos, pode-se pensar que, pelo menos, um terço da população de Cachoeira era negra e/ou parda.

Ao contrário do que Aurélio Porto pareceu querer inferir, desde o início da ocupação territorial de Cachoeira, a utilização do braço escravizado foi uma constante em diversas atividades produtivas como agrícolas, pastoris, domésticas ou manufatureiras. A historiadora Rosicler Fagundes observou que, entre o período 1845 a 1865, em uma amostra de 213 inventários post-mortem, $84 \%$ deles continham, na descrição dos bens arrolados, a presença de, pelo menos, um escravizado..$^{49}$ Nas décadas finais do século XIX, apesar dos efeitos do fim do tráfico e o impacto do comércio interno de escravizados, os números relativos à presença escravizada em Cachoeira ainda se mostravam

se denominou como História Pública. Joseli Maria Mendonça explica que "os historiadores praticam a História Pública quando produzem conteúdos para públicos ampliados - elaborando narrativas ou trabalhando com as instituições de preservação dos "artefatos" do passado (museus, arquivos, centros de documentação etc.) - e/ou quando problematizam tais conteúdos, tomando-os como objeto de estudo. Em qualquer uma dessas vertentes, as representações públicas do passado estão no cerne das preocupações de historiadores que se dedicam à História Pública” (MENDONÇA, Joseli Maria Nunes. Escravidão, Africanos e Afrodescendentes na "Cidade mais Europeia do Brasil": identidade memória e História Pública. Tempos Históricos, v. 20, 2016, p. 219).

${ }^{48}$ FAGUNDES, op. cit., p.47.

${ }^{49}$ Ibidem, p. 63. 
importantes, pois, entre 1871 a 1887 , em aproximadamente $49 \%$ dos inventários post-mortem analisados havia escravizados entre os bens inventariados. ${ }^{50}$

De acordo com o censo de 1872, a população do município de Cachoeira somava 11.756 habitantes, entre os quais $18,17 \%$ eram escravizados e representavam um percentual maior em relação ao total da população escravizada da província (15,59\%). ${ }^{51} \mathrm{O}$ quadro a seguir traz informações que merecem ser mais detalhadas sobre a composição étnica do município:

Tabela 1: População de Cachoeira por cor

\begin{tabular}{c|c|c|c|c}
\hline Total Habitantes & Brancos & Pardos & Pretos & Caboclos \\
\hline 11756 & 7867 & 1970 & 1870 & 549 \\
\hline $100 \%$ & $66,9 \%$ & $16,75 \%$ & $15,26 \%$, & $4,66 \%$ \\
\hline
\end{tabular}

Fonte: DIRETORIA Geral de Estatística. Recenseamento Geral do Império de 1872. op. cit. p. 91.

A partir do recenseamento por cor, percebe-se que 37,33\% da população do município de Cachoeira eram não-brancos. Situação semelhante Melina Perussatto verificou em Rio Pardo, onde 36,5\% da população eram pretos, pardos e caboclos, dado que, segundo a historiadora, também se aproxima de Rio Grande. ${ }^{52}$ Em Santa Maria, Ênio Grigio constatou que, no censo de 1872 , esse número apresenta-se ainda maior, uma vez que a população não-branca era quase a metade dos habitantes recenseados. ${ }^{53}$ Soma-se a isso o fato que a condição da cor no período está fortemente ligada à condição jurídica, o que pode subrepresentar esses dados.

Tabela 2: População de Cachoeira por condição jurídica e cor

\begin{tabular}{c|c|c|c|c|c}
\hline Condição jurídica & Brancos & Pardos & Pretos & Caboclos & Totais \\
\hline Livres & 7367 & 1104 & 600 & 549 & 9620 \\
\hline$\%$ & $76,58 \%$ & $11,47 \%$ & $6,23 \%$ & $5,70 \%$ & $100 \%$ \\
\hline Escravizados & --- & 866 & 1270 & --- & 2136 \\
\hline$\%$ & --- & $40,54 \%$ & $59,45 \%$ & --- & $100 \%$ \\
\hline
\end{tabular}

Fonte: DIRETORIA Geral de Estatística. Recenseamento Geral do Império de 1872, op. cit, p. 91.

\footnotetext{
${ }^{50}$ SÔNEGO, op. cit., p. 44.

${ }^{51}$ DIRETORIA Geral de Estatística. Recenseamento Geral do Império de 1872. Rio de Janeiro: Typ. Leuzinger / Tip. Commercial, 1876, v. 11, p. 205.

${ }^{52}$ PERUSSATTO, op. cit., p. 230.

${ }^{53}$ GRIGIO, Ênio. "No alvoroço da festa, não havia corrente de ferro que os prendesse, nem chibata que intimidasse": a comunidade negra e sua Irmandade do Rosário (Santa Maria, 1873-1942). Santa Maria: Câmara Municipal de vereadores de Santa Maria, 2018, p. 94.
} 
Somente em relação à população livre, a população não-branca correspondia a 23,42\%. É importante salientar que esse censo representa também a emergência de novos atores sociais na paisagem sulina, os imigrantes alemães, trazendo maior impacto representativo para a população branca. Em Cachoeira, 1217 pessoas recenseadas eram de nacionalidade alemã, sendo que esse dado em relação ao total da população branca de Cachoeira representa um percentual de $15,46 \% \cdot{ }^{54}$ Neste sentido, pode-se analisar como a imigração europeia serviu aos seus objetivos intrínsecos de branqueamento da população no Brasil.

As planícies alagáveis do rio Jacuí foram o palco para a criação pelo governo provincial da Colônia de Santo Ângelo em 1855, sendo que, a partir de 1857, chegaram os primeiros colonos alemães. Eram terras consideradas devolutas, compostas em grande parte por matos e que seriam propícias para o desenvolvimento da agricultura..$^{55} \mathrm{O}$ incentivo pela ocupação e povoamento desconsiderava, por sua vez, qualquer ocupação humana ali existente, visto que, em ocasião da demarcação dos lotes coloniais, os "agricultores de descendência portuguesa já ali residentes foram removidos para a chamada linha Brasileira". ${ }^{56}$ O vazio demográfico e a ausência de atividades agrícolas sempre foram a justificativa para implementação de projetos colonizatórios que, na sua esteira, traziam a civilização aos espaços a serem ocupados. A ideia de uma terra rica, porém inóspita, que só passível de transformação através do trabalho árduo de imigrantes estrangeiros foi a tônica de um discurso de exaltação da história da imigração. A passagem a seguir sintetiza bem um ideal que perdurou na história do município de Cachoeira e serviu como um "mito fundador" da colonização alemã na região:

Os colonos haviam sido enganados, pois se lhes afirmava que desembarcariam em Santa Cruz, para onde, constava, seriam destinados. Ao se aproximarem de Rio Pardo, disseram-lhes que, devido á cheia do Jacuí, teriam de ir adiante. Ao chegarem ao

\footnotetext{
${ }^{54}$ DIRETORIA Geral de Estatística. Recenseamento Geral do Império de 1872. op. cit, p. 92.

${ }^{55} \mathrm{~A}$ historiografia sobre a formação da estrutura agrária no Rio Grande do Sul destaca a preferência inicial na ocupação das terras de campos, mais propícias para a pecuária, das quais foram possuídas essencialmente através da concessão de sesmarias. Enquanto as áreas florestais eram ocupadas em menor escala, e em grande parte, eram consideradas devolutas, foram apropriadas mais lentamente, na medida em que a fronteira agrária ia se fechando para as ocupações primárias (ZARTH, Paulo A. Do arcaico ao moderno: O Rio Grande do Sul agrário do século XIX. Ijuí: Ed. Unijuí, 2002). No caso do município de Cachoeira, Alejandro Gimeno observou, através da análise dos Registros Paroquiais de Terras, que a apropriação agrária corrobora a constatação anterior, apontando que as terras de campo consistiam 72,49\% das declarações, em 17,49\% eram parcelas de terra com campos e matos e apenas 10\% eram áreas florestais (GIMENO, op. cit., p. 40). ${ }^{56}$ WERLANG, Willian. História da Colônia de Santo Ângelo. Santa Maria: Pallotti, 1995, p.14.
} 
Sêrro Chato, passo sobre o Jacuí, onde deveriam desembarcar, os colonos relutaram, tentando revoltar-se. Então a tripulação do vapor, fê-los sair à força. Um espetáculo emocionante desenrolou-se alí. Quase loucos de terror, vendo-se naquele deserto, esmagados pela brutalidade impiedosa da mata virgem, ouvindo o uivo das feras, os colonos queriam voltar novamente para o vapor. A tripulação teve, então de empenhar-se em luta contra eles, enquanto o vapor largava, deixando-os sós. (...) Cincoenta anos mais tarde, já numa terra rica e prospera, nadando em abundância, e toda povoada e cultivada, os filhos e netos desses colonos celebraram a festa do cinquentenário, a que assistiram ainda alguns dos velhos troncos remanescentes do povoamento, e alí apareceu, quando eles vestidos com seus trajes primitivos, simularam a cena do desembarque, o mesmo velho mulato que os havia levado, e com que eles lutara para que ficassem. Em 1907, nessa festa, ainda compareceram os últimos sobreviventes dos 119 chegados em $57 .^{57}$

Muitas passagens chamam atenção nessa narrativa, as quais foram grifadas na citação anterior. A primeira delas, a já evidenciada ausência de civilização naquele rude território, dos quais os bravos colonos não puderam fugir, mas que, a partir dali, ergueu-se grande prosperidade. A segunda passagem é a festa de comemoração do cinquentenário da colonização alemã daquela comunidade, em que se dramatizou a história da colonização, criando uma narrativa bem-sucedida dos acontecimentos e forjando, assim, uma construção histórica vitoriosa.$^{58} \mathrm{~A}$ terceira passagem, que casualmente ou não aparece na narrativa, dá conta de que um "velho mulato" que teria participado do "convencimento físico" daqueles colonos para que ficassem no lugar aportado. Seria esse "velho mulato" um escravizado que acompanhava a comitiva do brigadeiro José Gomes Portinho ${ }^{59}$ que também estava na embarcação, cuja presença incômoda foi retratada em momento especialmente crucial do mal-estar que os colonos foram submetidos?

Não se tem estudos específicos sobre as relações entre os colonos alemães e a população negra em Cachoeira, seja ela escravizada ou livre, assim

\footnotetext{
${ }^{57}$ PORTO, O trabalho alemão... op. cit., p. 169-170.

58 "As performances funcionam como atos de transferência vitais, transmitindo o conhecimento, a memória e um sentido de identidade social" (TAYLOR, Diana. O arquivo e o repertório: performance e memória cultural nas Américas. Belo Horizonte: UFMG, 2013, p. 27).

${ }^{59}$ Presidiu a comissão de vereadores para tratar sobre o núcleo de colonização.
} 
como com os povos indígenas. ${ }^{60}$ As pesquisas até agora desenvolvidas sobre esse recorte espacial partem de uma separação entre "dois mundos": colonos europeus e populações não-brancas, como se essas pessoas não se comunicassem ou disputassem os mesmos espaços, sejam territoriais ou simbólicos. ${ }^{61}$

Neste sentido, recuperam-se dessas pesquisas algumas passagens que deixam implícita essas relações. Conforme Marcos Tramontini, a lei imperial n. ${ }^{\circ}$ 514, em 24 de outubro de 1848, no seu artigo 16, sobre o desenvolvimento de projetos de colonização, determinava que não poderiam ser "roteadas" por escravos. Esse fato, por sua vez, não impediu a posse de escravizados na Colônia de São Leopoldo, o que levou à promulgação da lei geral n.․․ 304 de 30 de novembro de 1854, mas que não se mostrou efetiva para tal, visto que se observou a continuidade do trabalho escravizado que, muitas vezes, foi mais coibido por questões econômicas, uma vez que a aquisição de um escravizado por colonos que detinham pouco capital, posto que alemães que se dedicavam a atividades comerciais e manufatureiras tiveram escravizados a seu dispor interdependente da legislação proibitiva. ${ }^{62}$

Na pesquisa de mestrado, analisou-se todos os inventários do período de 1871 a 1888 para identificar os proprietários escravistas e não-escravistas de Cachoeira nas décadas finais da escravidão. No entanto, não se identificou em nenhum dos inventários de pessoas com sobrenome alemão que tivessem, na sua composição patrimonial, escravizados. ${ }^{63}$ Porém ao pesquisar nos fundos notariais, verificaram-se transações comerciais que trazem compradores e vendedores de escravizados com sobrenomes alemães, assim como algumas

\footnotetext{
${ }^{60} \mathrm{~A}$ historiografia sobre a colonização europeia tem apontado que para além do desenvolvimento da produção agrícola como esta serviu aos objetivos de branqueamento da população, assim como a "varredura" das terras até então ocupadas pelos indígenas. A formação das colônias seguiu, preferencialmente, os cursos fluviais da depressão central da província do Rio Grande do Sul. A ocupação destas áreas florestais, por sua vez, não competia com o latifúndio que se estendia principalmente sobre as áreas de campos, onde a pecuária era melhor desenvolvida (BRINGMANN, Sandor F. Kaingang vs. colonos: um fenômeno de fronteiras étnico-geográficas no Rio Grande do Sul do século XIX. Histórica-Revista Eletrônica do Arquivo Público do Estado de São Paulo, no 35, 2009; HERÉDIA, Vânia. A imigração europeia no século passado: o programa de colonização no Rio Grande do Sul. Scripta Nova. Revista Eletrónica de Geografia e Ciencias Sociales. Universidad de Barcelona, v. 5, nº 94, 2001, s/p. Disponível em: http://www.ub.edu/geocrit/sn-94-10. htm. Acesso em: 10 jan. 2020).

${ }^{61}$ Nesse sentido, dialogamos com trabalhos que estudam esta relação em outras localidades do Rio Grande
do Sul: MAGALHÃES, Magna L. Entre a preteza e brancura brilha o Cruzeiro do Sul: associativismo e identidade
negra em uma localidade teuto-brasileira. Tese (Doutorado em História). UNISINOS, 2010; CARVALHO,
Daniela Vallandro de. "Entre a solidariedade e a animosidade": Os Conflitos e as Relações Interétnicas Populares
Santa Maria - 1885 a 1915. Dissertação (Mestrado em História). UNISINOS, 2005.
}

${ }^{62}$ TRAMONTINI, Marcos J. A escravidão na colônia alemã. Disponível em: http://cdn.fee.tche.br/jornadas/1/ s5a3.pdf. Acesso em: 10 jan. 2020.

${ }^{63}$ SÔNEGO, op. cit. 
cartas de alforrias apresentam sobrenomes germânicos. Em alguns deles, pairam dúvidas sobre a vinculação com a Colônia de Santo Ângelo, que mereceriam uma investigação mais criteriosa, o que extrapolaria os objetivos da presente pesquisa. Mas se observou que, em pelo menos um dos casos, o do proprietário João Kunz (Kuns) está discriminado o seu local de moradia como sendo a referida colônia. Ele vendeu o escravizado Claudino em 20 de junho de 1879 e, na mesma data, registrou a compra da escravizada Luciana, que era de posse de Pedro Müller Júnior. ${ }^{64} \mathrm{Em} 1884$, ele alforriou Luciana "com a condição de a escrava, avaliada em 1:000\$, "prestar os seus serviços ao senhor Israel Antônio Cardoso da Rosa a ele ou a seus herdeiros ou a quem ele determinar, pelo prazo de 7 anos a contar desta data, serviços estes que prestará onde o referido senhor [...] determinar [...]". No mesmo ano, alforriou a escravizada Manoela, "avaliada em 1:000\$, "sob as condições de me prestar os seus serviços, a mim ou a meus herdeiros ou a quem eu determinar, pelo prazo de 7 anos a contar desta data serviços esses que prestará onde eu determinar, [...] ficando entendido que durante o referido prazo não poderá ausentar-se de minha casa ou de onde estiver empregada sem expresso consentimento meu ou de meus herdeiros ou sucessores". ${ }^{65}$ Isso implica afirmar que, assim como Ênio Grigio observou em Santa Maria, a propriedade de escravizados por alemães não foi um fato isolado e que a escravidão estava capilarizada nos diversos grupos sociais. ${ }^{66}$ Até mesmo o Vigário Marcolino da Maia Firme, da Paróquia da Nossa Senhora da Conceição de Cachoeira, comprou duas escravizadas, Joaquina e Eusébia, nos anos de 1874 e 1876, respectivamente. ${ }^{67}$

Carlos Eduardo Piassani em sua pesquisa de mestrado ao recuperar as trajetórias de políticos alemães no Rio Grande do Sul no século XIX, traz algumas informações sobre as aparentes contradições de figuras atuantes como Barão von Kahlden. ${ }^{68}$ Apesar da proibição da utilização do trabalho cativo nas

\footnotetext{
${ }^{64}$ RIO GRANDE DO SUL. Secretaria da Administração e dos Recursos Humanos. Departamento de Arquivo Público. SCHERER, Jovani de Souza; ROCHA, Márcia Medeiros (Coord.). Documentos da escravidão: compra e venda de escravos, acervo dos tabelionatos do Rio Grande do Sul. Porto Alegre: CORAG, 2010, p.392.

${ }^{65}$ RIO GRANDE DO SUL. Documentos da escravidão: catálogo seletivo de cartas de liberdade ... op. cit. pp. 160 e 164.

${ }^{66}$ GRIGIO, op. cit. p.136.

${ }^{67}$ RIO GRANDE DO SUL. Documentos da escravidão: compra e venda de escravos... op. cit. pp. 379 e 385.

${ }^{68}$ Karl Hermann Johann Adam von Kahlden, conhecido como Barão von Kahlden, foi diretor da Colônia de Santo Ângelo entre 1857 a 1882. Paralelamente, exercia funções de agrimensor, especulador imobiliário e delegado de polícia, foi vereador em Cachoeira do Sul. Também atuou como construtor de pontes em obras do governo provincial e dirigiu a colônia de São Lourenço no ano de1868. Elegeu-se deputado provincial em 1888. Bem relacionado com a elite cachoeirense, casou-se, em 1855, com Carolina Cândida Gomes da Silva, que era filha de Antônio Candido Gomes da Silva, comissário-geral, vereador e latifundiário de Cachoeira. Cf. PIASSINI, Carlos Eduardo. Imigração Alemã e Política: os deputados provinciais Koseritz, Kahlden, Haensel, Brüggen e Bartholomay. Porto Alegre: Assembleia Legislativa do Rio Grande do Sul, 2017, p. 103.
} 
colônias alemãs, o diretor da Colônia de Santo Ângelo, que, a princípio teria de fazer por cumprir a lei entre os colonos, realizou transações comerciais para adquirir, pelo menos, seis escravizados para servir a si e a sua família, entre 1865 e 1877, na cidade de Cachoeira ${ }^{69}$ O Barão também não mediu esforços ao enviar correspondência ao governo provincial para garantir a anexação de maiores faixas de terras devolutas à colônia alemã, mesmo que, nelas, já estivessem ocupadas por trabalhadores nacionais ou "intrusos" que delas viviam a partir da extração de madeiras. ${ }^{70}$

Aliás, são os trabalhos que enfatizam as questões agrárias subjacentes à política imigrantista na região central da província do Rio Grande do Sul que retornam mais facetas desse complexo relacional interétnico. Alejandro Gimeno na sua dissertação de mestrado, recuperou, através dos Autos de Legitimação de Posse de Cachoeira, uma intensa movimentação na estrutura da posse agrária e que, a partir de meados do século XIX, intensificou-se, especialmente com a fundação dos núcleos de colonização alemã e, posteriormente, italiana que abarcou terras daquele município. ${ }^{71}$ Os loteamentos coloniais representaram uma forma de efetivar-se a Lei de Terra de 1850, ocasionando o fechamento da fronteira agrária aos camponeses e lavradores nacionais que até então acessavam a terra através da posse ou apropriação primária de terras devolutas. A partir da restrição da lei, a propriedade territorial ficou vinculada essencialmente a transações de compra, venda, herança ou doação.

A Lei de Terras tinha como objetivo regularizar a posse de terras que ficou sem uma regularização efetiva após o fim das concessões de sesmarias em 1822, exigindo-se o registro das terras de todas as formas de ocupação agrária, incluindo as sesmarias, com sua medição e demarcação a fim de validar efetivamente o título de propriedade. A historiografia tem demonstrado também a sua função em delimitar o acesso à terra pelos ex-escravizados. Isto porque, em 1850, também se efetivou a lei que proibiu o tráfico de escravizados para o Brasil e as discussões em torno da abolição da escravidão tornavam-se cada vez mais preeminentes, assim como as preocupações com a escassez da oferta de mão de obra levavam a medidas que evitassem o acesso à propriedade da terra aos futuros libertos e seus descendentes.

\footnotetext{
${ }^{69}$ RIO GRANDE DO SUL. Documentos da escravidão: catálogo seletivo de cartas de liberdade... op.cit. pp. 314, $354,383,384,388$ e 558.

${ }^{70}$ PIASSINI, op. cit., p.167.

${ }^{71}$ GIMENO, op. cit.
} 
Alejandro Gimeno verificou em Cachoeira o processo de legitimação dos proprietários de terras a partir da Lei de Terras que se apresentou de forma complexa, pois ao mesmo tempo em que a lei permitia a legitimação de pequenos posseiros, estes se viam impelidos muitas vezes pelos custos administrativos do processo de medição e documentação. Isso pode ter favorecido a usurpação dessas propriedades por outros agentes melhor situados socialmente que declararam a posse de áreas que, apesar de ocupadas, não estavam registradas. Ao mesmo tempo havia uma constante pressão de que novas áreas fossem destinadas à expansão da Colônia de Santo Angelo, cujo diretor, Barão von Kahlden, usava sua influência e prestígio junto à elite política local para beneficiar a expansão colonial em detrimento da posse não regularizada de pequenos posseiros nacionais. ${ }^{72}$

Dessa forma, nos finais do século XIX, conforme a população escravizada de Cachoeira foi conquistando lentamente a liberdade, o acesso à terra pela posse estava legalmente proibido e o acesso pela compra tornava-se ainda mais difícil devido à especulação imobiliária ocasionada pela demarcação e venda de lotes coloniais aos imigrantes alemães e posteriormente italianos. ${ }^{73}$ Se aos imigrantes europeus havia a possibilidade de financiamento dos lotes territoriais, aos nacionais e ex-escravizados o acesso ficou extremamente difícil, e quando o seu acesso ocorreu foi constantemente ameaçado e usurpado. ${ }^{74}$ Terras de matos eram comumente destinadas aos roçados e cultivos de escravizados para seu sustento, mas também serviam como justificativa aos grandes proprietários para requerer a posse de novas áreas junto aos autos de legitimação. ${ }^{75}$

\footnotetext{
${ }^{72}$ Ibidem, p. 59.

${ }^{73} \mathrm{O}$ núcleo colonial da Santa Maria da Boca do Monte, a partir de 1877, passou a receber imigrantes italianos e a denominar-se Colônia Silveira Martins. Além do território do município de Santa Maria, uma parcela importante do território de Cachoeira fez parte dos desdobramentos da política colonial com a criação de loteamentos particulares de colonização, abrangendo o território que atualmente convencionou-se chamar de $4^{\mathrm{a}}$ Colônia de Imigração Italiana. De acordo com Maíra Vendrame: "havia estrutura e uma série de recursos para atender às necessidades dos imigrantes, tudo sustentado pelos cofres públicos. Nada parecido foi feito para as populações que viviam no território sul-rio-grandense, por isso os italianos podem ser considerados privilegiados, já que foram beneficiados de diversas formas. Algumas características enfatizadas pela historiografia tradicional como, por exemplo, a de que os colonos se encontravam isolados e abandonados no meio das florestas, não servem para explicar sua situação na ex-Colônia Silveira Martins" (VENDRAME, Maíra I. "Lá Éramos Servos, Aqui Somos Senhores": A organização dos imigrantes italianos na ex-Colônia Silveira Martins (1877-1914). Dissertação (Mestrado em História). Pontifícia Universidade Católica do Rio Grande do Sul, 2007, p. 147).

${ }^{74}$ Sobre este processo ver: SILVA, Marcio Antônio Both da. Por uma lógica camponesa: caboclos e imigrantes na formação do agro no Planalto rio-grandense (1850-1900). Dissertação (Mestrado em História). Programa de Pós-graduação em História, UFRGS, 2004.

${ }^{75} \mathrm{Gimeno}$ descreve a justificativa de José Gomes Leal para legitimar as terras alagadiças próximas a Colônia
} 
Apesar das restrições, ainda assim famílias negras movimentaram-se em busca da aquisição de terras. São os casos de duas comunidades negras rurais localizadas no então território de Cachoeira, cujos fundadores acessaram a posse da terra pela compra. Esses dois núcleos foram reconhecidos como comunidades remanescentes de quilombos com base no artigo 68 do Ato das Disposições Constitucionais Transitórias da Constituição Federal de 1988, sendo eles o quilombo Cambará, situado em Cachoeira do Sul, próximo à divisa com o município de Caçapava do Sul, e o quilombo São Miguel, localizado atualmente no município de Restinga Seca. ${ }^{76}$

Marcelo Moura Mello dissertou sobre Cambará demonstrando que este nunca foi um território negro isolado, pois os quinhões adquiridos por dois ex-escravizados - antecessores de algumas famílias - nos anos de 1835, 1845 e 1855, eram encravados no interior de uma sesmaria e suas terras confrontavam com grandes estancieiros e pequenos plantadores. Escravizados, libertos e livres, mantinham estreitas relações de parentesco e compadrio entre si e ocuparam aquele território. ${ }^{77}$

Assim como Cambará, em São Miguel, a comunidade também teve sua ancestralidade na região comprovada através da compra de terras em 1892, por Geraldo Carvalho. Este era escravizado da família Carvalho Bernardes que tinha uma vasta área de terras na região com a posse de número acima da média de trabalhadores escravizados. A comunidade também foi circundada por propriedades de descendentes de imigrantes alemães e italianos que adquiriram lotes coloniais próximos e, com o passar dos anos, foi observado um processo de expropriação territorial daquela comunidade negra. ${ }^{78}$

A questão agrária sulina na historiografia mais recente avançou ao complexificar um panorama por muito tempo entendido como dicotômico entre latifundiários sulinos versus expropriados, trazendo à tona outros atores sociais que constituíram espectro bem mais irregular e conflituoso do que

de Santo Ângelo, onde tinha roçados milho e feijão e que ali estavam "dois escravos e familiares destes que os representavam na dita posse" (GIMENO, op. cit., p. 73-74). A prática da concessão de terras a posteiros e agregados foi uma solução empregada pelos grandes proprietários a fim de proteger seus desígnios territoriais, servindo como uma divisa limítrofe humana, uma vez que os campos não eram cercados (FARINATTI, Sobre as Cinzas da Mata Virgem, op. cit; ZARTH, op. cit.).

${ }^{76}$ Foram realizados laudos antropológicos e históricos para comprovar a ancestralidades daqueles territórios.

${ }^{77}$ MELLO, op. cit.

${ }^{78}$ ANJOS, José. LOPES, Dilmar, SILVA, Paulo. Laudo antropológico e etnohistórico sobre a comunidade rural negra remanescente de quilombo de São Miguel - Restinga Seca. Porto Alegre, 2002; SÔNEGO, Aline. Terra pr'a que te quero? A inserção social campesina da comunidade afrodescendente de São Miguel. Monografia (Especialização em História do Brasil), UFSM, 2005. 
dantes se descrevia. ${ }^{79}$ Neste sentido, a historiografia deve destacar também a composição étnica na ocupação fundiária, não isolando em sua análise os processos de imigração europeia, expulsão ou cooptação indígena e a posse por nacionais, livres e libertos. Apesar da construção de uma historicidade regional com fronteiras identitárias bem demarcadas, não se deve esquecer que na prática, estas questões identitárias territoriais estavam interligadas e foram geradoras de tensionamentos nas relações interétnicas.

\section{Considerações finais}

Como destacou-se no início neste artigo, os impressos das primeiras décadas do século XX contaram e representaram a história e a composição da população de Cachoeira estabelecendo critérios de representatividade que privilegiaram os brancos em relação aos não-brancos. Estes materiais tipográficos contribuíram para forjar uma identidade local que atrelou àquela região uma autorrepresentação relacionada à cultura europeia, propulsora do progresso, em detrimento da invisibilidade ou mitificação da presença das populações negra e indígena, como não mais pertencentes e àquela sociedade, desconsiderando os sujeitos e suas experiências socias, vinculando-as a um passado distante e quase mítico.

$\mathrm{Na}$ intenção de descontruir historicamente a referida ausência de negros e indígenas na formação da população da região, observou-se através das fontes documentais censitárias e estatísticas, a participação de diversos grupos étnicos na composição da região desde os primórdios de sua ocupação territorial. A partir desta análise, percebeu-se que os materiais impressos contam apenas parte da história daquela região, desprestigiando àqueles que em diversas passagens do processo histórico local foram subjugados, expulsos ou esquecidos, mesmo que seus braços e mentes também construíram aquela riqueza e povoaram aquelas terras fazendo parte da constituição daquele território. Processo esse não livre de tensionamentos e expropriações e que forjaram uma composição étnica bem mais diversa do que a propalada identidade europeia daquela região.

${ }^{79}$ FARINATTI, Luís Augusto E. Rumos da História Agrária no Rio Grande do Sul: resultados, fontes e possibilidades de pesquisa. In: REMEDI, José Martinho R. (Org). op. cit., p. 13. p. 290-29. 


\section{Referências}

ALBERTO, Paulina L. El Negro Raúl: Lives and Afterlives of an Afro-Argentine Celebrity, 1886 to the Present. Hispanic American Historical Review, 96:4, 2016, pp.669-710.

ANJOS, José. LOPES, Dilmar, SILVA, Paulo. Laudo antropológico e etnohistórico sobre a comunidade rural negra remanescente de quilombo de São Miguel - Restinga Seca. Porto Alegre, 2002.

ARAÚJO, Thiago Leitão. Escravidão, fronteira e liberdade: políticas de domínio, trabalho e luta em um contexto produtivo agropecuário (vila de Cruz Alta, província do Rio Grande do Sul, 1834-1884). Dissertação (Mestrado em História). Programa de Pós-graduação em História, UFRGS, 2008.

AUGUSTO, Ronald. Nem raro, nem claro. Porto Alegre: Butecanis Editora Cabocla, 2015.

ATLAS Socioeconômico Rio Grande do Sul. Porto Alegre: Secretaria do Planejamento, Governo e Gestão, 4 ed. 2019. Disponível em: <https:// atlassocioeconomico.rs.gov.br/demografia-1872-a-1980>. Acesso em: 7 jul. de 2021. BRINGMANN, Sandor F. Kaingang vs. colonos: um fenômeno de fronteiras étnicogeográficas no Rio Grande do Sul do século XIX. Histórica - Revista Eletrônica do Arquivo Público do Estado de São Paulo, nº 35, 2009.

CAMOZATO, Benjamin C. (Org.) Grande álbum de Cachoeira no Centenário da Independência do Brasil. Cachoeira do Sul: Município de Cachoeira, 1922.

CAMPOS, Vanessa Gomes de (Org.). Guia arquivos pessoais e coleções IHGRGS. Porto Alegre: Instituto Histórico e Geográfico do Rio Grande do Sul, Secretaria de Estado da Cultura do Rio Grande do Sul, 2013.

CARVALHO, Daniela Vallandro de. "Entre a solidariedade e a animosidade": Os Conflitos e as Relações Interétnicas Populares Santa Maria - 1885 a 1915. Dissertação (Mestrado em História). UNISINOS, 2005.

CHALHOUB, Sidney. Cidade Febril. Cortiços e epidemias na Corte Imperial. São Paulo: Companhia das Letras, 1996.

COMISSOLI, Adriano. Povoamento e governança pública: elites locais e Câmaras municipais no sul da América portuguesa (1693-1810). In: REMEDI, José Martinho R. (Org). Na Fronteira do Império: política e sociedade na Rio Pardo oitocentista. Santa Cruz do Sul: EDUNISC, 2018. 
CRUZ, Heloísa de Faria. São Paulo em papel e tinta: periodismo e vida urbana (18901915). São Paulo: Arquivo Público do Estado de São Paulo, 2013.

DIRETORIA Geral de Estatística. Recenseamento Geral do Império de 1872. Rio de Janeiro: Typ. Leuzinger / Tip. Commercial, 1876, v. 11.

DREYS, Nicolau. Notícias descritivas da província do Rio Grande de São Pedro do Sul. 4ed. Porto Alegre: Nova Dimensão, EDIPUCRS, 1990.

FAGUNDES, Rosicler Maria R. Esfaqueamento no Púlpito: o comércio e suas elites em Cachoeira do Sul na segunda metade do século XIX (1845-1865). Dissertação (Mestrado em História). Programa de Pós-graduação em História, UNISINOS, 2009.

FARINATTI, Luís Augusto E. Sobre as Cinzas da Mata Virgem: Lavradores Nacionais na Província do Rio Grande do Rio Grande do Sul (Santa Maria, 1845-1880). Dissertação (Mestrado em História). Programa de Pós-graduação em História. Pontifícia Universidade Católica do Rio Grande do Sul, 1999.

FARINATTI, Luís Augusto E. Confins Meridionais. Famílias de elite e sociedade agrária na fronteira sul do Brasil (1825-1865). Santa Maria: Ed. UFSM, 2010.

FARINATTI, Luís Augusto E. Rumos da História Agrária no Rio Grande do Sul: resultados, fontes e possibilidades de pesquisa. In: REMEDI, José Martinho R. (Org). Na Fronteira do Império: política e sociedade na Rio Pardo oitocentista. Santa Cruz do Sul: EDUNISC, 2018.

GIMENO, Alejandro J. F. Apropriações e comércio de terras na cidade de Cachoeira no contexto da imigração europeia (1850-1889). Dissertação (Mestrado em História). Programa de Pós-graduação em História. UFSM, 2014.

GRIGIO, Ênio. "No alvoroço da festa, não havia corrente de ferro que os prendesse, nem chibata que intimidasse": a comunidade negra e sua Irmandade do Rosário (Santa Maria, 1873-1942). Santa Maria: Câmara Municipal de vereadores de Santa Maria, 2018.

GUTFREIND, Ieda. A Historiografia rio-grandense. $2^{\mathrm{a}}$ ed. Porto Alegre: Ed. Universidade/UFRGS, 1992.

HERÉDIA, Vânia. A imigração europeia no século passado: o programa de colonização no Rio Grande do Sul. Scripta Nova. Revista Eletrónica de Geografia e Ciencias Sociales. Universidad de Barcelona, v. 5, nº 94, 2001, s/p. Disponível em: http://www.ub.edu/geocrit/sn-94-10.htm. Acesso em: 10 jan.2020.

JORNAL O Commercio, 14 de agosto de 1918. Cachoeira, Rio Grande do Sul. Anno XIX, n 976. Arquivo Histórico de Cachoeira do Sul. 
JORNAL O Commercio, 16 de agosto 1916. Cachoeira, Rio Grande do Sul. Anno XVII, no 872. Arquivo Histórico de Cachoeira do Sul.

JORNAL Rio Grande, 16 de novembro de 1911. Cachoeira, Rio Grande do Sul. Anno VII, $n^{\circ}$ 80. Arquivo Histórico de Cachoeira do Sul.

LAYTANO, Dante. 0 negro no Rio Grande do Sul. Terceira parte- aspecto folclóricociclo das lendas no Rio Grande do Sul. Estudos Ibero-americanos, XXI (2), dezembro, 2005, pp.187-201.

LIMA, Maurício L. Interfaces entre Gilberto Freyre e Dante Laytano: a "democracia gaúcha”. Semina, v. 12, no 1, 2013.

LIVRO DE REGISTROS. Delegacia de Polícia. Cachoeira. 1887. Arquivo Histórico de Cachoeira do Sul.

MAGALHÃES, Magna L. Entre a preteza e brancura brilha o Cruzeiro do Sul: associativismo e identidade negra em uma localidade teuto-brasileira. Tese (Doutorado em História). UNISINOS, 2010.

MATHEUS, Marcelo Santos. Fronteiras de liberdade: escravidão, hierarquia social e alforria no extremo sul do Império do Brasil (província do Rio Grande de São Pedro, Alegrete, 1829-1888). Dissertação (Mestrado em História). Programa de Pósgraduação em História. UNISINOS, 2012.

MELLO, Marcelo Moura. Caminhos criativos da história: territórios da memória em uma comunidade rural negra. Dissertação (Mestrado em Antropologia Social). Programa de pós-graduação em Antropologia Social. UNICAMP, 2008.

MELO, Karina M. R. da Silva e. A aldeia de São Nicolau do Rio Pardo: identidades indígenas em construção. In: REMEDI, José Martinho R. (Org). Na Fronteira do Império: política e sociedade na Rio Pardo oitocentista. Santa Cruz do Sul: EDUNISC, 2018.

MENDONÇA, Joseli Maria Nunes. Escravidão, Africanos e Afrodescendentes na "Cidade mais Europeia do Brasil": identidade memória e História Pública. Tempos Históricos, v. 20, p. 218-240, 2016.

MENSAGEM. Intendente Capitão Francisco Fontoura Nogueira da Gama ao Conselho Municipal em 20 de setembro de 1917. Arquivo Histórico de Cachoeira do Sul.

MOREIRA. Paulo R. S; MATHEUS, Marcelo. As matrículas de escravos da capitania de São Pedro do Rio Grande: análise dos plantéis de cativos das freguesias de Mostardas, Cachoeira e Triunfo - década de 1780. Anais do 6ํㅡㄹ Entro Escravidão e Liberdade no Brasil Meridional. UFSC, 2013. 
NEUMANN, Eduardo Santos. Uma fronteira tripartida: a formação do continente do Rio Grande - século XVIII. In: GRIJÓ, Luiz Alberto, et.al. Capítulos de história do Rio Grande do Sul. Porto Alegre: ed. UFRGS, 2005, pp.25-46.

OLIVEIRA, Renata Saldanha. Cativos julgados: experiencias sociais escravas de autonomia, sobrevivência e liberdade em Cachoeira do Sul na segunda metade do século XIX. Dissertação (Mestrado em História). Programa de Pós-graduação em História, UFSM, 2013.

OSÓRIO, Helen. Apropriação de terra no Rio Grande de São Pedro e a formação do espaço platino. Dissertação (Mestrado em História). Programa de Pós-graduação em História, UFRGS, 1990.

PERUSSATTO, Melina K. "A todo preto questionava se era livre ou escravo": considerações sobre a Rio Pardo escravista e desigual (1860-1888). In: REMEDI, José Martinho R. (Org). Na Fronteira do Império: política e sociedade na Rio Pardo oitocentista. Santa Cruz do Sul: EDUNISC, 2018.

PIASSINI, Carlos Eduardo. Imigração Alemã e Política: os deputados provinciais Koseritz, Kahlden, Haensel, Brüggen e Bartholomay. Porto Alegre: Assembleia Legislativa do Rio Grande do Sul, 2017.

PORTELA, Vitorino de C., PORTELA, Manoel de C. Cachoeira histórica e informativa. Cachoeira: Tipografia Portela, 1940.

PORTO, Aurélio. Cachoeira. Resumo Histórico. In: CAMOZATO, Benjamin C. (Org.). Grande álbum de Cachoeira no Centenário da Independência do Brasil. Cachoeira do Sul: Município de Cachoeira, 1922.

PORTO, Aurélio. O trabalho alemão no Rio Grande do Sul. Porto Alegre: Martins Livreiro, 1996.

RIO GRANDE DO SUL. Secretaria da Administração e dos Recursos Humanos. Departamento de Arquivo Público. Documentos da escravidão: catálogo seletivo de cartas de liberdade acervo dos tabelionatos do interior do Rio Grande do Sul. Porto Alegre: CORAG, 2006.

RIO GRANDE DO SUL. Secretaria da Administração e dos Recursos Humanos. Departamento de Arquivo Público. PESSI, Bruno Stelmach (Coord.) Documentos da escravidão: inventários: o escravo deixado como herança. Porto Alegre: CORAG, 2010.

RIO GRANDE DO SUL. Secretaria da Administração e dos Recursos Humanos. Departamento de Arquivo Público. SCHERER, Jovani de Souza; ROCHA, Márcia 
Medeiros (Coord.). Documentos da escravidão: compra e venda de escravos: acervo dos tabelionatos do Rio Grande do Sul. Porto Alegre: CORAG, 2010.

RITZEL, Mirian Regina Machado. Dicionário Bibliográfico Cachoeirense: natos e adotivos. Porto Alegre: Martins Livreiro, 2006.

ROSA, Marcus Vinicius de F. Além da invisibilidade: história social do racismo em Porto Alegre durante o pós-abolição. Porto Alegre, EST Edições, 2019.

SAINT-HILAIRE, Auguste de. Viagem ao Rio grande do Sul, 1820-1821. Belo Horizonte: Itatiaia; 1974.

SCHUH, Angela S.; CARLOS, Ione M. S. Cachoeira do Sul. Em busca de sua história. Porto Alegre: Martins Livreiro, 1991.

SELBACH, Jeferson F. Muito além da Praça José Bonifácio: as elites e os outsiders em Cachoeira do Sul pela voz do Jornal do Povo, 1930-1945. Tese (Doutorado em História). Programa de Pós-graduação em História, UNISINOS, 2007.

SILVA, Marcio Antônio Both da. Por uma lógica camponesa: caboclos e imigrantes na formação do agro no Planalto rio-grandense (1850-1900). Dissertação (Mestrado em História). Programa de Pós-graduação em História, UFRGS, 2004.

SÔNEGO, Aline. Sob a condição que continue em nossa companhia: As décadas finais da escravidão e a transição para o trabalho livre em um município rio-grandense. Dissertação (Mestrado em História). Programa de Pós-graduação em História, Universidade de Passo Fundo, 2011.

SÔNEGO, Aline. Terra pr'a que te quero? A inserção social campesina da comunidade afrodescendente de São Miguel. Monografia (Especialização em História do Brasil), UFSM, 2005.

TAMBARA, Elomar. A leitura escolar como construção ideológica: o caso na lenda do Negrinho do Pastoreio (1857-1906). Revista História da Educação, vol. 9, número 17, janeiro/junho, 2005.

TAYLOR, Diana. 0 arquivo e o repertório: performance e memória cultural nas Américas. Belo Horizonte: UFMG, 2013.

TELES, Jefferson M. O Instituto Histórico e Geográfico do Rio Grande do Sul e o espaço social dos intelectuais: trajetória institucional e estudo das redes de solidariedade (e conflitos) entre intelectuais (1920-1956). Tese (Doutorado em História), Pontifícia Universidade Católica do Rio Grande do Sul, 2015. 
THOMPSON FLORES, Mariana Flores da Cunha. Crimes de Fronteira: a criminalidade na fronteira meridional do Brasil (1845-1889). Tese (Doutorado em História). Programa de Pós-Graduação em História. Pontifícia Universidade Católica do Rio Grande do Sul. Porto Alegre, 2012.

TRAMONTINI, Marcos J. A escravidão na colônia alemã. Disponível em: http://cdn.fee. tche.br/jornadas/1/s5a3.pdf. Acesso em: 10 jan. 2020.

VENDRAME, Maíra I. "Lá Éramos Servos, Aqui Somos Senhores": A organização dos imigrantes italianos na ex-Colônia Silveira Martins (1877-1914). Dissertação (Mestrado em História). Programa de Pós-graduação em História, Pontifícia Universidade Católica do Rio Grande do Sul, 2007.

WERLANG, Willian. História da Colônia de Santo Ângelo. Santa Maria: Pallotti, 1995.

ZARTH, Paulo A. Do arcaico ao moderno: O Rio Grande do Sul agrário do século XIX. Ijuí: Ed. Unijuí, 2002.

Artigo enviado para publicação em 15/01/2021 Artigo aprovado para publicação em 30/07/2021 